\title{
Antioxidant Efficacy of Ananas Comosus Extract Against Renal Injury Induced by Sodium Oxalate in Rats
}

\author{
Amany A Sayed, Dina M Mohamed, Amel M Soliman and Sohair R Fahmy* \\ Zoology Department, Faculty of Science, Cairo University, Egypt
}

Submission: March 22, 2017; Published: June 15, 2017

*Corresponding author: Sohair R Fahmy, Zoology Department, Faculty of Science, Cairo University, Egypt, Tel: +20-1149939166; Email: sohairfahmy@gmail.com

\begin{abstract}
The present study was performed to evaluate the antioxidative efficacy of Ananas comosus fruit extract (ACFE) against sodium oxalate ( $\mathrm{NaOx}$ ) induced oxidative damage in rats. Thirty rats were divided mainly into control group and NaOx group (70mg/kgb.wt, i.p.). The last one was subdivided into 4 subgroups; rats received vehicle (untreated NaOx), and ACFE at 500, 750, and 1000mg/kg b.wt respectively concurrently with NaOx for seven days. ACFE improved the serum and urine creatinine, urea, uric acid levels. Further, ACFE reduced the renal LPO concentration and enhance the levels of antioxidant enzymes. The present study concluded that the ameliorative effect of ACFE may be due to its chemical active substances such as phenols, flavonoids, alkaloids, saponins, glycosides, triterpenes, and tannins. However, the antioxidative ability of ACFE-derived bioactive compounds should be further investigated as a natural remedy for kidney diseases.
\end{abstract}

Keywords: Ananas comosus; Sodium oxalate; Renooxidation; Phenolic compounds; Ascorbic acid (AA); Sodium oxalate (NaOx)

Abbreviation: ROSs: Reactive Oxygen Species; AOX: Antioxidants; ACFE: Ananas Comosus Fruit Extract; TAC: Total Antioxidant Capacity; AA: Ascorbic Acid; SOD: Superoxide Dismutase; LOP: Lipid Peroxide; GSH: Glutathione Reduced; GST: Glutathione-S- Transferase; SOD: Superoxide Dismutase

\section{Introduction}

Free radicals are extremely reactive species that initiate a series of harmful reactions in the cell. The balance between the production of reactive oxygen species (ROSs) and antioxidants (AOX) is vital in a biological system to eliminate the adverse effects of oxidative stress [1]. Increased production of ROSs and/ or reduced antioxidant systems rather than decreased efficiency in repairing the balance between both linked to several diseases. Reactive oxygen species play an important role in the genesis of calcium oxalate stone through free radical generation that eventually lead to lipid peroxidation causing renal injury $[2,3]$.

Previous studies demonstrated that oxalate disturbs the mitochondrial electron transport chain and induces the leakage of free radicals [4,5]. Dysfunction of the endogenous antioxidant systems during lithiasis or other pathological conditions increases oxidative stress [4]. Most of the ROSs is short lived and does not travel long distances and hence the generated free radical interacts rapidly with lipids, amino acids, proteins, carbohydrates and nucleic acids causing severe injury [6].

Sodium oxalate ( $\mathrm{NaOx}$ ), a strong dicarboxylic acid, is present in many foods such as cocoa, chocolates, almonds, pasta noodles [7]. It is produced in the body by metabolism of glyoxylic acid or ascorbic acid. It is not metabolized in the body, but is excreted inurine. Sodium oxalate generates oxidative stress via the release of malondialdehyde and reduction of the superoxide dismutase and catalase activities [8,9]. Wang et al. [10] clarified that $\mathrm{NaOx}$ elicits renal toxicity through oxidative stress in the kidney, resulting in DNA damage and cell apoptosis.

Lately, there is a great attention on the usage of natural plants in disease therapy all over the world. Thus, a prophylactic natural agents very important to control the onset and/or progression of diseases [11]. Fruits are generally one of the most consumed foods due to their sweet taste. Generally, fruits have healthpromoting properties due to their high AOX concentration. Some phytochemicals of fruits are strong AOX which reduce the risk of chronic diseases by protecting against free radical damage [12].

Ananas comosus (pineapple) is the most economically important plant in the family Bromeliaceae and it is widely grown in tropical and subtropical regions. Pineapple called as 'the king of fruit' due to its attractive crown leaves shape. It is consumed as a fresh and canned fruit, as well as in processed juices. A. comosus has immense health benefits as it contains considerable quantity of vitamins and essential trace elements. Additionally, it is rich 
with flavonoids and other phenolic compounds which enhance its antioxidant activities $[13,14]$. Thereby, Ananas comosus fruit extract (ACFE) may act as free radical scavengers and/or metal chelator that may prevent membrane lipid peroxidation. Thus, the present study was carried out to evaluate the antioxidative activity of different doses of ACFE against sodium oxalate mediated oxidative stress.

\section{Materials and Methods}

\section{Sample collection}

Fresh fruit pineapple, Anans comosus, belongs to the subfamily Bromelioideae, order Bromeliales, genus Ananas and species comosus [15] was purchased from local market in Giza, Egypt.

\section{Preparations of crude fruit extract of ananas comosus}

To prepare Ananas comosus fruit extract (ACFE), Ananas comosus fruit chopped into small pieces (Figure 1A), shade dried and coarsely powdered (Figure 1B-1D). 300g A comosus powder was soaked in $1 \mathrm{~L}$ of absolute ethanol. The extract was kept in the shaker for $24 \mathrm{~h}$ and the suspension was filtered. The extract obtained was evaporated in rotary evaporator and stored in a desiccator until used for various evaluations [16].

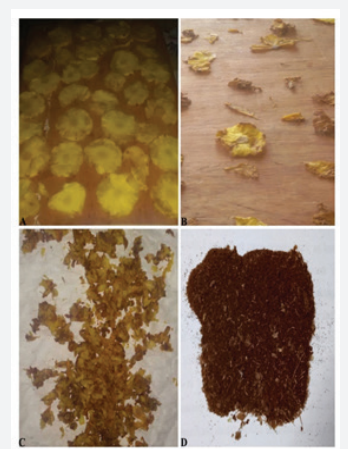

Figure 1: Preparation of Ananas comosus fruit extract. (A) Displays the ripe slices. (B) Shows air dried Ananas comosus. (C\&D) showing grinding of Ananas comosus.

\section{Determination of bioactive constituents of ACFE}

Test for phenols (ferric chloride test): The fraction of ACFE was treated with 5\% ferric chloride solution and observed for the formation of deep blue or black color which indicated the presence of a phenolic hydroxyl group.

Test for flavonoids (sodium hydroxide test): $0.2 \mathrm{~g}$ of ACFE was dissolved in water and then $2 \mathrm{ml}$ of the $10 \%$ sodium hydroxide was added. Yellow color appeared. A change in color from yellow to colorless on addition of dilute $\mathrm{HCl}$ was an indication for the presence of flavonoids [17].

Test for alkaloids (wagner's test): Fifty grams of the ACFE was boiled in $1 \% \mathrm{HCl}$, then cooled and filtered. On the filtrate the few drops of Wagner's test [2g of iodine and $6 \mathrm{~g}$ of potassium iodide in $100 \mathrm{ml}$ dist. Water] was added to $5 \mathrm{ml}$ filtrate and observed in the formation of reddish brown or a brown color precipitate.
Test for saponin (foam test): 10g of ACFE were boiled in $100 \mathrm{ml}$ dist. water, cooled and filtered. $5 \mathrm{ml}$ of the filtrate inserted in measuring cylinder and shaken vigorously for 15 minutes. Appearance of one $\mathrm{cm}$ (or more) layer of foam indicates the presence of saponin. i.e. a voluminous stable persistent froth (appearance of creamy miss of small bubbles) indicates the preliminary evidence for the presence of saponin. The frothing was mixed with 3 drops of olive oil and shaken vigorously. The formation of an emulsion indicates the presence of saponin.

Test for terpenoids (Salkowiski's test): To $0.5 \mathrm{~g}$ of the ACFE, add $2 \mathrm{ml}$ of chloroform. $3 \mathrm{ml}$ conc. $\mathrm{H}_{2} \mathrm{SO}_{4}$ was carefully added to form a layer. A reddish brown coloration of the interface indicates the presence of terpenoids.

Test for steroids and sterols (Liebermann-Burchard test): $0.2 \mathrm{~g}$ of ACFE was mixed with $10 \mathrm{ml}$ chloroform; then filtered. $2 \mathrm{ml}$ of the filtrate was added to $2 \mathrm{ml}$ acetic anhydride followed by carefully addition of $2 \mathrm{ml} \mathrm{H}_{2} \mathrm{SO}_{4}$. The appearance of a reddish violet color at the junction of the two layers and a bluish green color in the acetic layer indicates the presence of sterols.

Test for tannin (Acetic acid test): 200mg of ACFE was dissolved in $10 \mathrm{ml}$ dist. water and filtered. Few drops of acetic acid solutions were added to $5 \mathrm{ml}$ of filtrate. Formation of red color solution indicates the presence of tannins.

Test for glycosides (sulphuric acid test): To $2 \mathrm{ml}$ of ACFE, $1 \mathrm{ml}$ of glacial acetic acid and 5\%ferric chloride was added. Then few drops of sulphuric acid were added. Presence of greenish blue color indicates the presence of glycosides.

Test for carbohydrates (benedict's test): Five grams of the ACFE were boiled in $100 \mathrm{ml}$ dist. water and filtered. To $1 \mathrm{ml}$ of the filtrate, $5 \mathrm{ml}$ of Benedict's reagent was added and the mixture was heated. The appearance of red precipitate indicates the presence of reducing sugars.

\section{Test for quinones}

a. A small amount of ACFE was treated with concentrated $\mathrm{HCl}$ and observed for the formation of a yellow color precipitate.

b. About $0.5 \mathrm{~g}$ of extract was taken and added $1 \mathrm{ml}$ of extract and $1 \mathrm{ml}$ of conc. H2SO4. Formation of red color shows the presence of quinones.

Test for anthraquinones: $0.5 \mathrm{~g}$ of ACFE was boiled with $10 \%$ $\mathrm{HCl}$ for few min. The reaction mixture were filtered and allowed to cool. Equal volume of chloroform was added to each filtrate. Few drops of $10 \%$ ammonia was added to each mixture and heated. Rose-pink color indicates the presence of anthraquinones.

\section{Detection of resins}

To $5 \mathrm{~g}$ of the ACFE, add $50 \mathrm{ml}$ of $95 \%$ ethanol, boiled on a water bath for 20 minute, then filtered. Then, add $5 \mathrm{ml}$ dist. water. A white precipitate or turbidity indicates the presence of resins. Phytochemical screening of ACFE was performed according to Dhivya and Manimegalai [18]. 
In vitro total antioxidant capacity of ACFE: The total antioxidant capacity (TAC) assay was determined in ACFE to get an impressive about the cooperative action of antioxidants $[18,19]$. TAC of ACFE was determined spectrophotom etrically by the hydrogen peroxide (H2O2) assay using the method described by Koracevic et al. [18]. Briefly, 20 $\mu$ l of ACFE and ascorbic acid (AA) from each concentration was mixed with $500 \mu$ l of $\mathrm{H} 2 \mathrm{O} 2$. Incubation was then carried out for 10 minutes in a water bath at $37{ }^{\circ} \mathrm{C}$. Then, the absorbance of the solutions was measured using a UV-visible spectrophotometer at $505 \mathrm{~nm}$ against a blank (reagents without ACFE). TAC activity is expressed as the number of gram equivalent of ascorbic acid (mg /g AA). The calibration curve was prepared from $50-250 \mathrm{mg} / \mathrm{ml}$ methanol.

\section{Animals}

Male Wistar albino rats $(130 \pm 20 \mathrm{~g})$ were purchased from the National Research Center (Egypt). Animals were housed for one week in laboratory animal room of Zoology Department, Faculty of Science, Cairo University and free access to diet and tap water. Experiment was performed according to the guidelines of the Care and Use of Laboratory Animals ( $8^{\text {th }}$ edition) and the study was approved by the Institutional Animal Care and Use Committee (IACUC) (CUFS/S/PHY/25/14) of the Faculty of Science, Cairo University, Egypt.

\section{Experimental design and protocol}

Thirty male albino rats were divided randomly into the following groups $(n=6)$. Rats administered distilled water orally by gastric gavages (control group). NaOx group which intraperitoneally injected with $70 \mathrm{mg}$ sodium oxalate ( $\mathrm{NaOx}$ ) / kg b.wt for 7 days [20] and concurrently administered ACFE at three dosages $(500,750$ and $1000 \mathrm{mg} / \mathrm{kg}$ b.wt) orally by gastric gavages.

\section{Animal handling and specimen collection}

At the $8^{\text {th }}$ day, the rats were weighted and placed individually in the metabolic cage. Urine sample was collected for $24 \mathrm{~h}$ and measured by measuring cylinder. Then, the collected urine samples were centrifuge at $3000 \mathrm{rpm}$ for 10 minute and the urine supernatant was used for analysis of calcium, phosphorus, magnesium, creatinine, urea and uric acid using Biodiagnostic kits (Dokki, Egypt).After urine collection, the animals were euthanized and blood was collected by heart puncture. Blood was centrifuged for 10 minute at 3000rpm for serum preparation. Two kidneys were excised from each animal, weighed relative to its rat body weight. The right kidney immediately blotted by filter paper to remove traces of blood and stored at $-80^{\circ} \mathrm{C}$ for biochemical analysis.

\section{Serum analysis}

The collected serum was used for determination of kidney function markers such as creatinine [21], urea and uric acid [22].

Kidney homogenate preparation and analysis: A 10\% kidney tissue homogenate was prepared using Tris- $\mathrm{HCl}$ buffer
(0.1 M, pH 7.4). The homogenate was centrifuged at $860 \times \mathrm{g}$ for 15 min. at $4{ }^{\circ} \mathrm{C}$ and the obtained supernatant was used to determine the oxidant/antioxidant markers. Then, lipid peroxide (LPO) [23], glutathione reduced (GSH) [24], glutathione- S- Transferase (GST) [25], superoxide dismutase (SOD) [26] and catalase [27] were determined according to manufactures instructions using Bio-diagnostic kits (Giza, Egypt).

Statistical analysis: Data are presented as mean \pm SEM. Statistical differences between groups were statistically analyzed using one-way ANOVA post hoc by Duncan's test. A p value $<0.05$ considered statistically significant. SPSS software was used for statistical computations.

Results

\section{Preliminary phytochemical screening}

Preliminary phytochemical analysis of ACFE revealed the existence of phenols, flavonoids, alkaloids, saponins, terpenoids, steroids and sterol, tannins, glycosides, carbohydrates, quinines and absence of anthraquinone and resins (Table 1).

Table 1: +: Presence; -: Absence.

\begin{tabular}{|c|c|}
\hline Test & + \\
\hline Phenols & + \\
\hline Flavonoids & + \\
\hline Alkaloids & + \\
\hline Saponins & + \\
\hline Terpenoids & + \\
\hline Steroids\&Sterols & + \\
\hline Tannins & + \\
\hline Glycosides & + \\
\hline Carbohydrates & + \\
\hline Qunthraquinone & + \\
\hline Resins & + \\
\hline
\end{tabular}

\section{Total antioxidant capacity of ACFE}

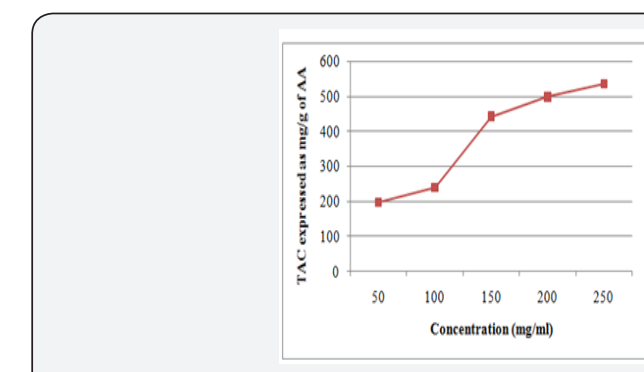

Figure 2: Total antioxidant capacity (TAC) of ACFE. AA: ascorbic acid. 
Figure 2 showed that ACFE has high TAC activity. The results indicate that TAC of ACFEis concentration dependent. It means that the ACFE contain as much quantity of antioxidants compounds as equivalents of ascorbic acid (AA) to effectively reduce the oxidants in the matrix.

\section{Effect of ACFE on serum and urinary creatinine concentration of $\mathrm{NaOx}$ treated rats}
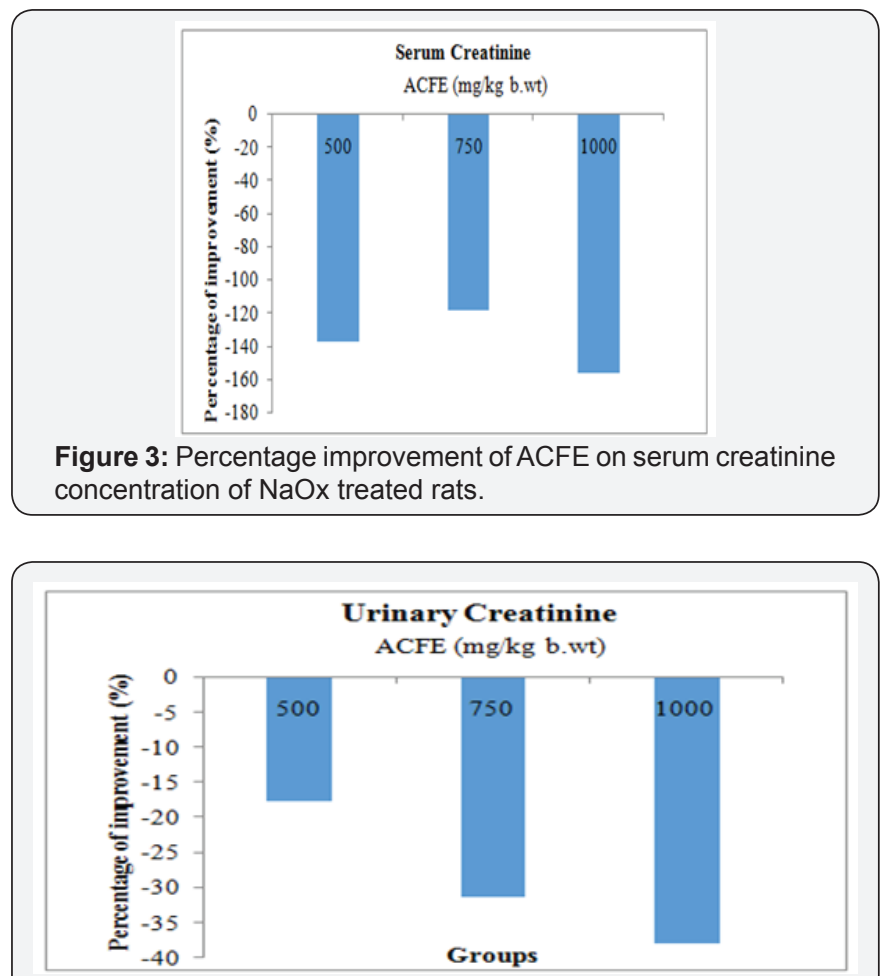

Figure 4: Percentage improvement of ACFE on urinary creatinine concentration of $\mathrm{NaOx}$ treated rats.

Figures 3 and Figure 4 display that ACFE (500, 750, 1000mg/ $\mathrm{kg}$ b.wt) improved the increased serum creatinine level of $\mathrm{NaOx}$ treated rats with $137.6 \%, 118.8 \%, 156.52 \%$ respectively, and with $17.6 \%, 31.3 \%, 37.92 \%$ regarding the urinary creatinine level. Moreover, a marked increase in the creatinine clearance was observed after co-treatment with ACFE (500,750 and

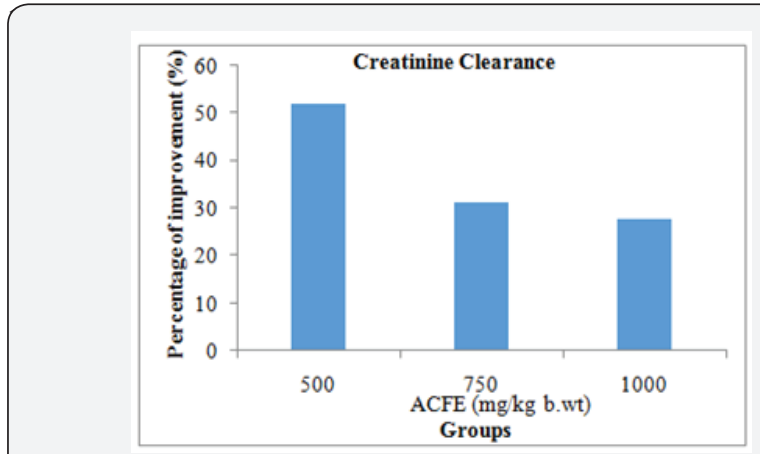

Figure 5: Percentage improvement of ACFE on creatinine clearance of $\mathrm{NaOx}$ treated rats.

\section{Effect of ACFE on serum and urinary urea concentration} of $\mathrm{NaOx}$ treated rats

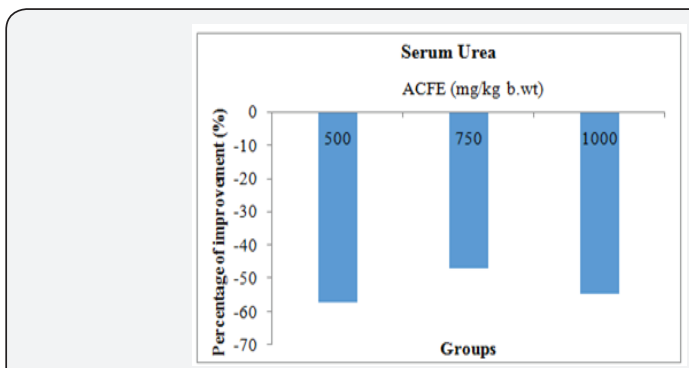

Figure 6: Percentage improvement of ACFE on serum urea concentration of $\mathrm{NaOx}$ treated rats.

Concurrent administration of NaOx and ACFE $(500,750$ and $1000 \mathrm{mg} / \mathrm{kgb} . w \mathrm{t}$ ) for 7 days caused amelioration on serum urea level other than the $\mathrm{NaOx}$ treated only group with percentage of improvement $57.2 \%, 46.9 \%$, and $54.8 \%$, respectively and with percentage of $81.1,71.6$, and 80.1 for urinary urea concentration Figure 6 and Figure 7.

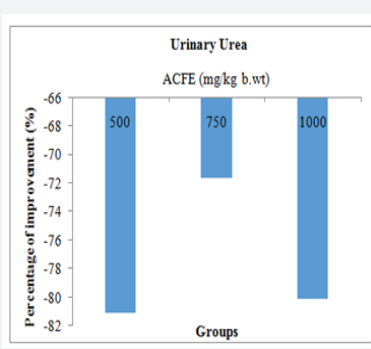

Figure 7: Percentage improvement of ACFE on urinary urea concentration of $\mathrm{NaOx}$ treated rats.

Effect of ACFE on serum and urinary uric acid concentration of $\mathrm{NaOx}$ treated rats

It is obvious that ACFE treatment not only reduced the elevated serum uric acid level of $\mathrm{NaOx}$ treated group, but also restored this level to normal value. Since, ACFE $(500,750$ and $1000 \mathrm{mg} / \mathrm{kg}$ b.wt) improved the altered serum uric acid level to $47.1 \%, 43.5,47.1 \%$. Similarly, concurrent administration of ACFE to NaOx group recovered the urine uric acid level to $47.5 \%$, 43.3\%, 49.5\% (Figure 8).

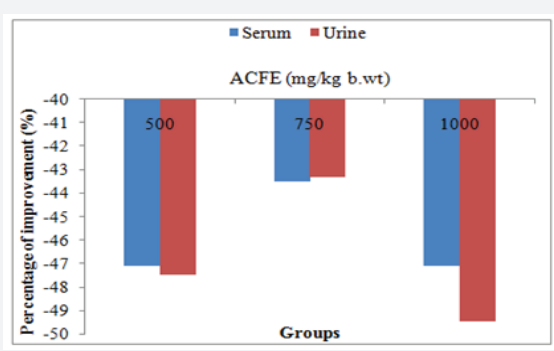

Figure 8: Percentage improvement of ACFE on serum and urinary uric acid $\mathrm{NaOx}$ treated rats.

Effect of ACFE on oxidative and antioxidative markers of $\mathrm{NaOx}$ treated rats 
A marked amelioration in the renal LPO was observed after the NaOx group co-treated with ACFE $(500,750$ and $1000 \mathrm{mg} /$ $\mathrm{kg}$ b.wt). This amelioration manifested by percentage decline reached to $51.3 \%, 71.5 \%, 45.7 \%$ than the increased LPO level of untreated $\mathrm{NaOx}$ group (Figure 9).

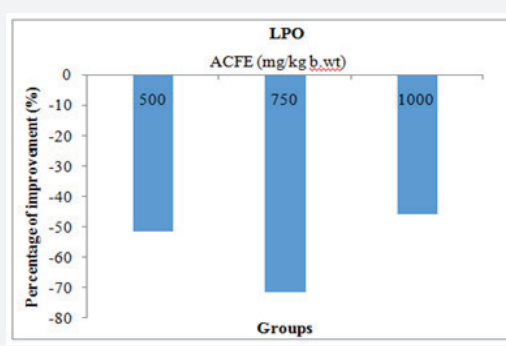

Figure 9: Percentage improvement of ACFE on renal lipid peroxide (LPO) concentration of $\mathrm{NaOx}$ treated rats.

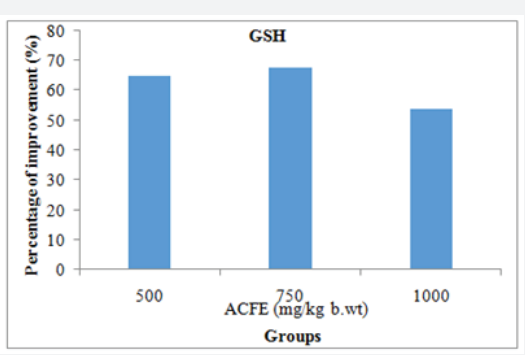

Figure 10: Percentage improvement of ACFE on renal glutathione $(\mathrm{GSH})$ concentration of $\mathrm{NaOx}$ treated rats.

Regarding the GSH concentration, its low $\mathrm{NaOx}$ value was enhanced by $56.1 \%, 67.8 \%$, and $54 \%$ upon administration of ACFE (500, 750 and $1000 \mathrm{mg} / \mathrm{kg}$ b.wt) (Figure 10). Further, injection of $\mathrm{NaOx}$ with ACFE $(500,750$, and $1000 \mathrm{mg} / \mathrm{kg}$ b.wt $)$ treatment improved the renal GST concentration (49.3\%, 38.5\%, $47.29 \%$ ) than the untreated $\mathrm{NaOx}$ group (Figure 11 ).

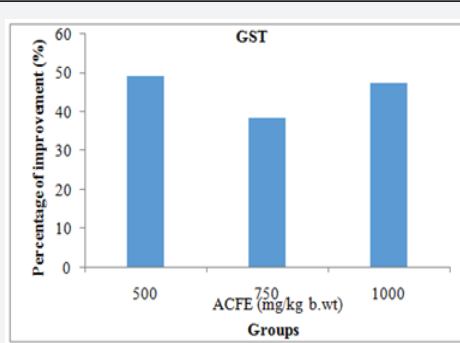

Figure 11: Percentage improvement of ACFE on renal glutathione-s-transferase (GST) concentration of $\mathrm{NaOx}$ treated rats.

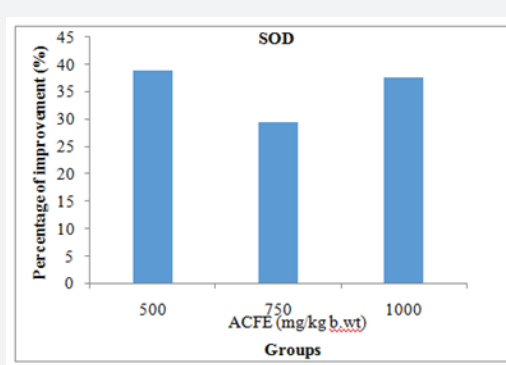

Figure 12: Percentage improvement of ACFE on renal superoxide dismutase (SOD) concentration of $\mathrm{NaOx}$ treated rats.

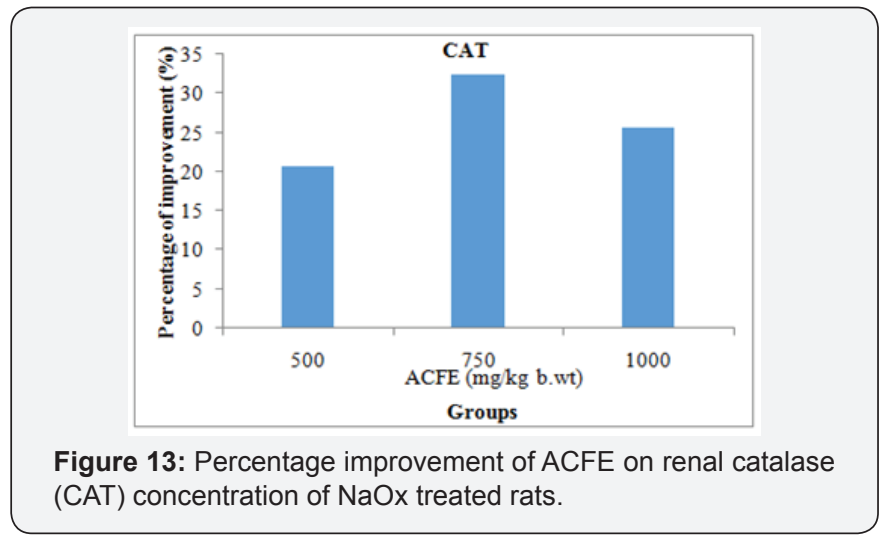

Figure 12 displays that ACFE $(500,750$ and $1000 \mathrm{mg} / \mathrm{kg}$ b.wt) has the ability to improve the renal SOD of NaOxtreated rats to $38.8 \%, 29.3 \%, 37.4 \%$. Likewise, oral administration of ACFE $(500,750$ and $1000 \mathrm{mg} / \mathrm{kg}$ b.wt) increased the renal CAT concentration of $\mathrm{NaOx}$ treated group with percentage of $20.75 \%$, 32.35\%, 25.68\% (Figure 13).

\section{Discussion}

Reactive oxygen species (ROS) contribute to the pathogenesis of numerous human degenerative diseases [1]. Phytoextracts are being commonly used to cure a wide variety of clinical disorders due to its ability to scavenge ROSs. Notably, plantbased compound mixtures generally have low or no toxic side effects [28]. Thus, great attention is being paid on the medicinal plants to avoid drug induced toxicity in the cell [9]. In this context, the purpose of the present study is to evaluate the in vivo antioxidative capacity of the extract of one of the most important fruits (Ananas comosus) against ROSs induced by sodium oxalate $(\mathrm{NaOx})$.

The present investigation revealed that ACFE ameliorates the altered renal markers such as creatinine, urea, and uric acid in serum and urine. These findings reflected the diagnosis of renal toxicity due to $\mathrm{NaOx}$ injection. This is on parallel with the results of Takawale et al. [29]; İlhan et al. [30]; Pawar \& Vyawahare [20]. The current study supposed that the renotoxicity of $\mathrm{NaOx}$ backed to the overproduction of ROSs provoked by it. This supported by the report of Ojha et al. [31], who demonstrated that ROS induced lipid peroxidation is a marker of cellular oxidative damage and is an important pathogenic event in renal injury. This interpretation is matching with the renal oxidative influx caused by NaOx. Since, the current study revealed that oral administration of ACFE decline the increased LPO level in kidney which means the increased renal LPO due to $\mathrm{NaOx}$ injection. This finding is parallel with Saha \& Verma [8]

Thamilselvan et al. [32] clarified that oxalate binds with the membrane proteins of the cell subsequently can induce lipid peroxidation by oxalate-enzyme interaction due to its chelating activity. Further, oxalate leads to the initiation of lipid signaling pathways and hence causing the overproduction of ROS and exhausting of the endogenous AOX enzymes and/or molecules [33]. Indeed, the present study evidenced that an improvement 
in the AOX system was occurred after the $\mathrm{NaOx}$ rats received ACFE which confirmed the relationship between the increased level of LPO and the decline in the level of AOX enzymes (GST, SOD, CAT) in this study. The potency of ACFE to express GSH, SOD, and CAT confirms the ability of ACFE to detoxify free radicals. This manifested by the mechanistic cascade of ROSs production (Figure 14).

$$
\begin{aligned}
& \text { SOD } \\
& 2 \mathrm{O}_{2}^{+}+2 \mathrm{H}^{+} \longrightarrow \mathrm{H}_{2} \mathrm{O}_{2}+\mathrm{O}_{2} \\
& \text { CAT } \\
& 2 \mathrm{H}_{2} \mathrm{O}_{2} \longrightarrow 2 \mathrm{H}_{2} \mathrm{O}+\mathrm{O}_{2} \\
& \text { GPx } \\
& \mathrm{H}_{2} \mathrm{O}_{2}+2 \mathrm{GSH} \longrightarrow 2 \mathrm{H}_{2} \mathrm{O}+\mathrm{GSSG}
\end{aligned}
$$

Figure 14: Schematic representation of the antioxidant enzymes and the reactions they

catalyze.SOD for superoxide dismutase, CAT for catalase, GPx for glutathione peroxidase, GSH for reduced glutathione (monomeric glutathione), GSSG for oxidized glutathione (glutathione disulfide) Bhattacharya et al. [9].

Since, GSH is one of intracellular non protein thiols compound which contribute in second lineof defense as a substrate or cofactor for GSH-dependent enzymes to detoxify ROS generated toxic byproducts and arrest propagation of free radicals [34]. Moreover, GSH serves as a cofactor for the GST which helps to remove certain drugs and chemicals as well as other reactive molecules from the cells. SOD played a major role to scavenge superoxide anion, whereas CAT detoxifies hydrogen peroxide by catalyzing a reaction between two hydrogen peroxide molecules, resulting in the formation of water and oxygen (Figure 14). This is in line with Saha and Verma [8], who reported that AOX therapy reduced renal toxicity through inhibition of membrane lipid peroxidation. Thereby, the present study demonstrated that ACFE administration reduced the ROSs by decreasing the LPO level and increasing the level of AOX substances such as GSH, GST, SOD, and CAT.

The present study attributes the antioxidative ability of ACFE to its bioactive compounds. Since, this study proved that ACFE contains a large pool of natural products, including phenols, flavonoids, alkaloids, saponins, glycosides, triterpenes, and tannins which may modulate multiple molecular pathways involved in the pathobiology of complex diseases. Where, healthbeneficial role of natural extracts arising from synergistic or additive effects of pools of natural products which affirm that the sum of the whole compound is more than its single entities [28].

It has been reported that the phenolic compounds present in the natural extracts may be responsible by virtue of their hydrogen-donating capacity that confirming scavenging ability of such extracts [8]. Indeed, the present study revealed the high TAC content of ACFE. Further, flavonoids (present in ACFE) have the ability to capture and neutralize the oxidizing agents and stimulate the AXO enzymes such as SOD and CAT [35]. This emphasizes the increasing percent of these enzymes after ACFE administration. Karamac' et al. [36] reported that tannins (present in ACFE) have the ability to chelate metal ions and retard oxidation specifically lipid peroxide. Moreover, saponin (present in ACFE) was its activity on lipid hydroperoxide and oxidative stress [37].

\section{Conclusion}

The present study indicates that sodium oxalate induced renal tissue damages due to oxidative stress influx. However, the polyphenolic rich compounds of ACFE have prophylactic role in sodium oxalate induced renal damage and oxidative stress. Thus, ACFE may be effective as renoprotective agent and hence further work should be performed to identify and purify its bioactive substance to be utilized in therapeutic implications. There is no marked variation between ACFE doses, so this study recommend the low one $(500 \mathrm{mg} / \mathrm{kg} \mathrm{b.wt})$ to be used in the future.

\section{References}

1. Barbagallo M, Marotta F, Dominguez LJ (2015) Oxidative stress in patients withAlzheimer's disease: effect of extracts of fermented papaya powder. MediatorsInflamm 2015: 1-6.

2. Guo C, McMartin KE (2005) The cytotoxicity of oxalate, metabolite of ethylene glycol, is due to calcium oxalate mono- hydrate formation. Toxicology 208(3): 347-355.

3. Sailaja B, Bharathi K, Prasad KVSRG (2012) Role of Tridaxprocumbens Linn. in the management of experimentally induced urinary calculi and oxidative stress in rats. Indian Journal of Natural Products and Resources 3(4): 535-540.

4. Jonassen JA, Cao LC, Honeyman T, Scheid CR (2003) Mechanisms mediating oxalate-induced alterations in renal cell functions. Crit Rev Eukaryot Gene Expr 13(1): 55-72.

5. Jonassen JA, Cao LC, Honeyman T, Scheid CR (2004) Intracellular events in the initiation of calcium oxalate stones. Nephron ExpNephrol 98(2): e61-e64.

6. Khan SR (2013) Reactive Oxygen Species as the molecular modulators of calcium oxalate kidney stone formation: Evidence from Clinical and Experimental Investigations. The journal of urology 189(3): 803-811.

7. Gul Z, Monga M (2014) Medical and dietary therapy for kidney stone prevention. Korean J Uro 155(12): 775-779.

8. Saha S, Verma RJ (2014) Polyphenolic extract of Piper nigrum inhibits sodium oxalate induced oxidative stress in rat kidney. Toxicology and Environmental Health Sciences 6(3): 164-169.

9. Bhattacharya D, Bhakta MS (2016) Renal and hepato protective effects of green tea (Camellia sinensis) extract on wistar rats treated with sodium oxalate. Int J Pharm Bio Sci 7(4): 740-746.

10. Wang H, Li D, Hu Z, Zhao S, Zheng Z, et al. (2016) Protective effects of green tea polyphenol against renal injury through ros-mediated JNK-MAPK pathway in lead exposed rats. Mol Cells 39(6): 508513.

11. Akila L, Kumar PA, Nirmala P (2011) Effect of a polyherbal formulation on ethylene glycol induced urolithiasis. International Journal of Pharma and Bio Sciences Research 2(4): 994-997.

12. Prior RL, Cao G (2000) Analysis of botanicals and dietary supplements for antioxidant capacity: a review. J AOAC Int 83(4): 950-956. 


\section{Journal of Complementary Medicine \& Alternative Healthcare}

13. Mhatre M, Tilak-Jain J, De S, Devasagayam TP (2009) Evaluation of the antioxidant activity of non-transformed and transformed pineapple: a comparative study. Food ChemToxicol 47(11): 2 696-2702.

14. Hossain A, Rahman SM (2010) Total phenolics, flavonoids and antioxidant activity of tropical fruit pineapple. Food Research International 44(3): 1-7.

15. Bartholomew DP, Paull RE, Rohrbach KG (2003) The Pineapple: Botany, Production and Uses. CTAHR, University of Hawaii, USA.

16. Balakrishnan A, Kokilavani R (2011) In vitro free radical scavenging activity of ethanolic extract ofCucumistrigonusRoxburxii fruit International Journal of Pharmaceutical \& Biological Archives 2(5): 1439-1444.

17. Dhivya R, Manimegalai K (2013) Preliminary phytochemical screening and GC- MS profiling of ethanolic flower extract of Calotropisgigantea Linn (Apocynaceae). J Pharmacognosy Phytchem 2(3): 28-32.

18. Koracevic D, Koracevic G, Djordjevic V, Andrejevic S, Cosic V (2001) Method for the measurement of antioxidant activity in human fluids. J ClinPathol 54(5): 356-361.

19. Apak R, Güçlü K, Demirata B, Ozyürek M, Celik SE, et al. (2007) Comparative evaluation of various total antioxidant capacity assays applied to phenolic compounds with the CUPRAC assay. Molecules 12(7): 1496-1547.

20. Pawar AT, Vyawahare NS (2017) Protective effect of ethyl acetate fraction of Biophytumsensitivum extract against sodium oxalateinduced urolithiasis in rats. Journal of Traditional and Complementary Medicine.

21. Bartles H, Bohmer M, Heirli C (1972) Colorimetric kinetic method for creatinine determination in serum and urine. Clin Chem Acta 37: 193.

22. Tietz NW, Finley P, Pruden E, Amerson A (1990) Clinical guide to laboratory tests Saunders. Philadelphia, USA, pp. 232-233.

23. Ohkawa H, Ohishi N, Yagi K (1979) Assay for lipid peroxides in animal tissues by thiobarbituric acid reaction. Analytical Biochemistry 95(2): 351-358.

24. Beutler E, Duron O, Kelly BM (1963) Improved method for the determination of blood glutathione. J Lab Clin Med 61: 882-888.

25. Habig WH, Pabst MJ, Fleischner G, Gatmaitan Z, Arias IM, et al. (1974) The identity of glutathione S-transferase B with ligandin, a major binding protein of liver. Proc Natl Acad Sci U S A 71(10): 3879-3882.
26. Nishikimi M, Appaji RN, Yagi K (1972) The occurrence of superoxide anion in the reaction of reduced phenazine methosulfate and molecular oxygen.Biochem Biophys Res Commun 46(2): 849-854.

27. Aebi H (1984) Catalase in vitro. Methods Enzymol 105: 121-126.

28. Weidner C, Rousseau M, Plauth A, Wowro SJ, Fischer C, et al. (2016) Iberisamara extract induces intracellular formation of reactive oxygen species and inhibits colon cancer. PLoSOne 11(4): e0152398.

29. Takawale RV, Mali VR, Kapase CU, Bodhankar SL (2012) Effect of Lagenariasiceraria fruit powder on sodium oxalate induced urolithiasis in Wistar rats. J Ayurveda Integr Med 3(2): 75-79.

30. İlhanM, Ergene B, Süntar I, Ozbilgin S, SaltanÇitoğlu G, et al. (2014) Preclinical evaluation of antiurolithiatic activity ofViburnum opulus L. on sodium oxalate-induced urolithiasis rat model. Evid Based Complement Alternat Med 2014: 578103.

31. Ojha S, Alkaabi J, Amir N, Sheikh A, Agil A, et al. (2014) Withania coagulans fruit extract reduces oxidative stress and inflammation in kidneys of streptozotocin-induced diabetic rats. Oxid Med Cell Longev 2014: 201436.

32. Thamilselvan V, Menon M, Thamilselvan S (2014) Oxalate at physiological urine concentrations induces oxidative injury in renal epithelial cells: effect of $\alpha$-tocopherol and ascorbic acid. BJU Int 114 (1): $140-150$

33. Moriyama MT, Suga K, Miyazawa K, Tanaka T, Higashioka M, et al. (2009) Inhibitions of urinary oxidative stress and renal calcium level by an extract of QuercussalicinaBlume/QuercusstenophyllaMakino in a rat calcium oxalate urolithiasis model. Int J Urol 16(4): 397-401.

34. Nakchat O, Nalinratana N, Meksuriyen D, Pongsamart S (2014) Tamarind seed coat extract restores reactive oxygen species through attenuation of glutathione level and antioxidant enzyme expression in human skin fibroblasts in response to oxidativestress.Asian Pac J Trop Biomed 4(5): 379-385.

35. Calado JCP, Albertão PA, de Oliveira EA, Letra MHS, Sawaya ACHF, et al (2015) Flavonoid contents and antioxidant activity in fruit, vegetables and other types of food. Agricultural Sciences 6(4): 426-435.

36. Karamać M (2009) Chelation of Cu (II), Zn (II) and Fe (II) by tannin constituents of selected edible nuts. Int J MolSci 10(12): 5485-5497.

37. Rodrigues HG, Diniz YS, Faine LA, Galhardi CM, Burneiko RC et al (2005) Antioxidant effect of saponin: potential action of a soybean flavonoid on glucose tolerance and risk factors for atherosclerosis. Int ] Food SciNutr 56(2): 79-85.

\section{Your next submission with Juniper Publishers will reach you the below assets}

- Quality Editorial service

- Swift Peer Review

- Reprints availability

- E-prints Service

- Manuscript Podcast for convenient understanding

- Global attainment for your research

- Manuscript accessibility in different formats

(Pdf, E-pub, Full Text, Audio)

- Unceasing customer service

Track the below URL for one-step submission

https://juniperpublishers.com/online-submission.php 